\title{
PARAMETRIC ASSESSMENT OF DISASTER RISK PREPAREDNESS LEVEL IN ALLEPPEY, KERALA
}

\author{
Geena Kuruvilla ${ }^{1}$, Jawahar Saud $\mathbf{S}^{\mathbf{2}}$ \\ ${ }^{1}$ Post Graduate Student, Department of Civil Engineering, Federal Institute of Science and Technology, Ernakulam, \\ Kerala, India \\ ${ }^{2}$ Assistant Professor, Department of Civil Engineering, Federal Institute of Science and Technology, Ernakulam, \\ Kerala, India
}

\begin{abstract}
The goal of disaster preparedness level is to regain the life of the people and structure while reducing the risk and vulnerability of the area. The low preparedness among the population towards structural safety and the failure of administrative authorities or technical experts in maintaining quality principles of constructions has made a dire need to educate the pioneers, adopting training and preparedness meeting to the community about the outcomes of disaster surge. This study attempts to focuses on the parametric assessment of surge or flood preparedness level in the inclined locales of Alleppey and to determine the risk zones followed to explore the countermeasures for the zones. The relative investigation of the areas with greater risk has been surveyed to assess the degree of cultural equivalence in predictors of flood preparedness. The questionnaire survey was subjected to peer reviews and statistical analysis using SPSS and analytical analysis using Weighted Arithmetic Mean Method, Importance Index Method were carried out for preparedness phase. The prime obstacles were identified as lack of preparedness tool, early warning system, preparedness meeting, $72 \mathrm{hr}$ disaster kit. Thus, the study concludes with implications, future research strategies with the necessity of effective disaster plans that can assist the individuals to prepare, recover, mitigate from disaster.
\end{abstract}

Keywords: Disaster, Surge, Building, Likert Scale, Risk, Preparedness.

$* * *$

\section{INTRODUCTION}

The majority of damage in the event of a disaster is due to improper planning, lack of preparedness level, poor infrastructural facilities, ignorance of the building standards, low quality substitutes of building materials and absence of site examinations. The four phases of disaster management should be emphasized in the construction that includes the preparedness, mitigation, prevention and recovery. Surge is a sort of natural disaster which of most part bursts out rapidly and is hard to control. It's a sudden calamity or devastation that roll out changes to our present circumstances of the life style and may bring up loss of property, life and environmental issues and additionally harm to the infrastructure. The state of Kerala is prone to a host of natural hazards such as floods, coastal erosion, droughts, lightning, landslides and earthquakes. Almost all the districts of Kerala are multi hazard prone. Floods, landslides and lightning are the most commonly occurring natural hazards.

\subsection{Need for Preparedness}

For a developing country like India which is vulnerable against floods, the preparedness level is very less which can bring about severe losses following after a severe disaster. Despite the facts that the Disaster Management Act, 2005 and the National Policy on Disaster Management, 2009 were passed and put into the impact at the national level.
Examines demonstrate that developed countries like Japan, New Zealand, USA etc. have effective local emergency warning systems and adequate preparedness among the residents which substantially reduced the losses brought about during the amid real surges. Population pressure and unsustainable land utilize practices prevailing in the state are the primary explanations behind the risk of hazards to transform into disaster events. Absence of proper infrastructure facilities and surpassing of carrying capacity are the cause of many of the anthropogenic threats.

Disasters are occurring common in every area, to every structure. Here forth, we can do is to assemble the preparedness level and furthermore take up various precautionary strides so that the impacts can be decreased. As a civil engineer, before the development of a building we ought to consider the typical catastrophes and the safeguards that should be finished. The event of the debacles can't be lessened. Thus, upgrading the prosperity or wellbeing and quality of the inclusive community and the structures are essential. The present study can be reached out by including the impact of the disaster administration specialists and the organisation experts.

A Flood Risk Assessment (FRA) is an assessment of the risk of flooding from all flooding systems, the distinguishing proof of surge mitigation measures and ought to give 
exhortation on actions to be made before and amid a flood. This work gives the detailed analysis of accessible data to inform the disaster management authority of flood risk at an individual site and recommend to the developer any preparedness and mitigation measures.

\subsection{Importance of the Study}

This study focuses on the assessment of Flood preparation levels of individual at household and group levels and thereby building up the countermeasure to expand the degree of preparedness both at household and community levels thus to minimize the losses or damages. Questionnaire surveys are carried out among the public residing in the most vulnerable regions of Alleppey, with a random sample. The questionnaires were developed based on variable which are observed to be the indicators of preparedness from numerous studies. These include hazard perception and optimistic inclination, response efficacy and outcome anticipation, demographic characteristics, hazard proximity, previous experience, critical awareness, behavioural intentions, perceived protection responsibility, risk communication or public education. The preliminary and detailed analysis of the surveys are performed with the assistance of Statistical method SPSS (Statistical Package for Social Science) and Analytical Method using Weighted Arithmetic Mean Method (WAM) and Importance Index Method (IIM).

\subsection{Objectives}

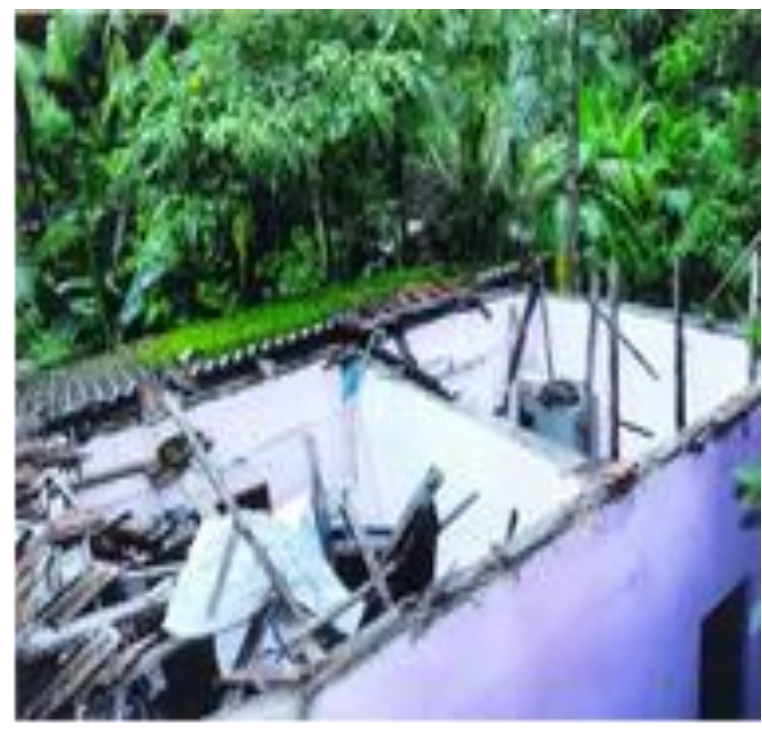

The various goals of this study are:

i. To measure the preparedness levels of the residents and compare with the correlational factors in the community.

ii. To determine the risk parameters in the zone that affecting the community.

- To compare the risk parameters by using statistical analysis and analytical method of analysis.

- To identify the type of buildings that has got heavy damages during the disaster.

- To propose countermeasures to reduce the damages and hence, the development of disaster management plan for the area.

\section{METHODOLOGY}

\subsection{Study Area}

Alleppey is chosen for the purpose of this study. The average depth of water level ranges from 0.5 to 12 metre below ground level(mbgl). Statistical analysis indicates that such events might recur in 100 years, plus or minus about 30 years. The fundamental reason behind flooding is because to absence of proper infrastructure facilities, high intensity of rainfall causes severe floods and increasing flood plains occupancy, reclamation of water bodies and wet lands increments the flood damages. Population pressure and unsustainable land use practise are another major reason of such calamity (census data, 2011).

Fig -1:. Damages caused due to the disaster

The fig 1 shows the heavy damages that has been caused in the area with the effects of the disaster. In Alleppey, the disaster also happens because of the overflow of water from water bodies such as river, lake or ocean. It may occur due to the accumulation of rain water on saturated ground in the areal flood. Fresh water flooding of $59 \%$, wind of $12 \%$, surf of $11 \%$, offshore of $11 \%$, surge of $4 \%$, others of $2 \%$, tornado of $1 \%$. Hence if the risk factors are identified the damages to

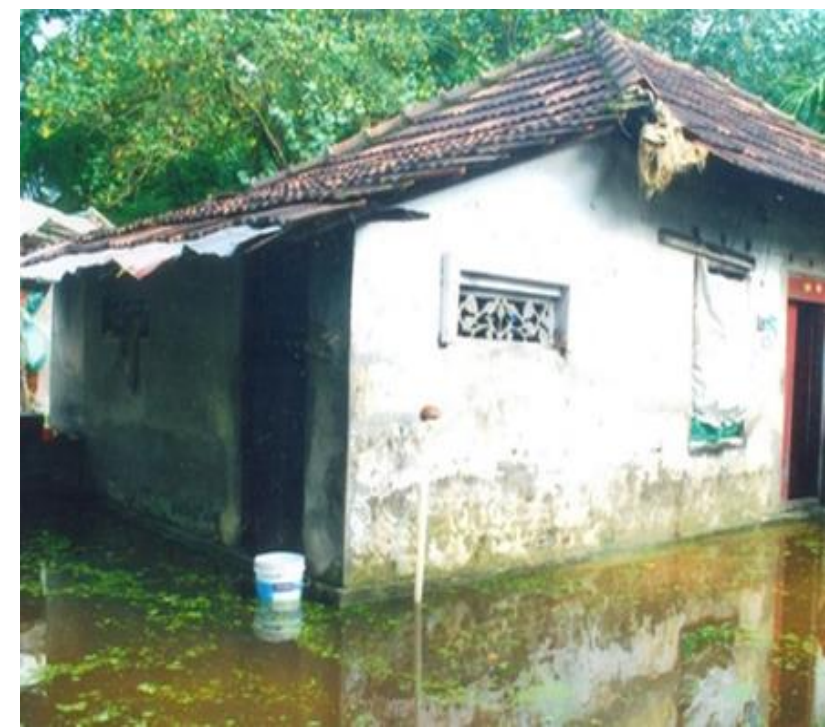

the property, structure can be lowered.

\subsection{Population, Sampling and Data Collection}

The population area of the study are divided into two Blocks, Block A and Block B. Block A covers Moncompu, Kuttanadu, Thalavady region and Block B covers Bharanaikavu, Kidangara region in Alleppey of Kerala State. 
A random selection of 50 samplers actively involved in the questionnaire survey. The areas were selected based on the previous disaster situations occurred and the responses from state disaster management authorities. From every area covering randomly around 10 samplers with different category to build up the result to be accurate. The respondents included were graduates, local people, students etc. The different buildings are also covered which includes residential building, commercial building, public buildings. The survey gone on more than 3 months. For about 70 questionnaires were comprised and 50 samples were collected with proper responses from the areas.

\section{DATA ANALYSIS AND RESULT}

Two analysis method are used in the study. Statistical analysis which were carried out using SPSS software and the ranking parameters generated are compared with analytical methods such as Weighted Arithmetic Mean (WAM) and Importance Index Method (IIM). The evaluation of each element is conducted considering the weightage average of the responses. The IIM and WAM Method is used to get the weightage average to rank the causes of risk parameters. Data analysis was carried out with statistical approach of mean and frequency analysis using the Importance Index (II) Method.

\subsection{Statistical Method of Analysis Using SPSS}

The statistical analysis is carried out using SPSS (Statistical Package for Social Science) software. It aimed to investigate the probability of occurrence for each factor in the study area using Five point Likert Scale as 1 for Strongly Disagree, 2 for Disagree, 3 for Neutral or I don't know, 4 for Agree and 5 for Strongly Agree. It involves respondents from the community SDMA (State Disaster Management Authority) and DDMA (District Disaster Management Authority) for relevant inputs. The Table 1 shows the major causes and effects of the calamity from the survey conducted which is been computed using SPSS.

Table -1: Preliminary analysis result for the cause and effects of calamity

\begin{tabular}{|l|l|l|l|}
\hline No & Causes & Effects & Rank \\
\hline 1 & $\begin{array}{l}\text { Preparedness } \\
\text { tool }\end{array}$ & $\begin{array}{l}\text { Damages to the } \\
\text { life and to the } \\
\text { building is very } \\
\text { high. }\end{array}$ & 1 \\
\hline 2 & $\begin{array}{l}\text { Proper } \\
\text { awareness and } \\
\text { early warning } \\
\text { system }\end{array}$ & $\begin{array}{l}\text { Improper } \\
\text { comprehensive } \\
\text { plans, } \\
\text { specifications for } \\
\text { building } \\
\text { construction. }\end{array}$ & 2 \\
\hline 3 & $\begin{array}{l}\text { Proper } \\
\text { training of } \\
\text { preparedness } \\
\text { level }\end{array}$ & $\begin{array}{l}\text { People has no } \\
\text { confidence in law, } \\
\text { in protecting and } \\
\text { maintain the } \\
\text { community. }\end{array}$ & \\
\hline
\end{tabular}

\begin{tabular}{|l|l|l|l|}
\hline 4 & $\begin{array}{l}\text { FPP (Flood } \\
\text { preparedness } \\
\text { program) }\end{array}$ & $\begin{array}{l}\text { People have no } \\
\text { trust the local } \\
\text { government to } \\
\text { respond to meet } \\
\text { their needs. }\end{array}$ & 3 \\
\hline
\end{tabular}

\subsection{Analytical Method of Analysis}

Analytical method implies solving using the derived equations to determine exact solutions for variational problems. The Analytical Method of solving the parameters includes Weighted Arithmetic Mean and Importance Index Method. The technique gives accurate ranking result.

The top five ranking parameters and the countermeasures are identified based on the result tabulation. Comparison with the statistical method to prove the same risk parameters to get the weighted average to rank the causes of risk parameters and the level of preparedness.

\section{i. Weighted Arithmetic Mean Method}

$$
\text { Weighted mean } \overline{\mathbf{x}}=\frac{\sum_{\mathbf{i}=\mathbf{1}}^{\mathrm{n}}\left(\mathbf{w}_{\mathbf{i}} \times \mathbf{x}_{\mathbf{i}}\right)}{\sum_{\mathbf{i}=\mathbf{1}}^{\mathbf{n}} \mathbf{w}_{\mathbf{i}}}
$$

Where, $\mathrm{w}_{\mathrm{i}}$ - the weights assigned to each parameter $\mathrm{x}_{\mathrm{i}}$ - the number of respondents for that weights $\bar{x}$ - mean

\section{ii. Importance Index Method}

Importance Index II = (Weighted average x 100)/5

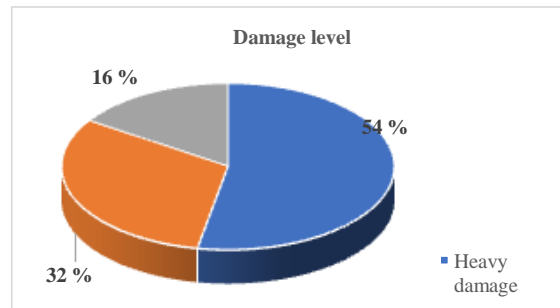

Chart -1: Damage level in the disaster

The Chart 1 shows the amount of damages that is caused for each respondent in the community. About $54 \%$ percent has effected by heavy loss or damage, $32 \%$ percent has been effected by minor damage and $16 \%$ percent has been effected by no loss. The Table 2 shows the comparision of the risk, vulnerability of Block $\mathrm{A}$ and Block $\mathrm{B}$ with the preparedness level which is less in Block B. 
Table -2: Comparison of vulnerability and risk for Block A and Block B

\begin{tabular}{|l|l|l|l|l|l|}
\hline Block & Risk & Vulnerability & $\begin{array}{l}\text { Pre- } \\
\text { Level }\end{array}$ & Rank & $\begin{array}{l}\text { Result- } \\
\text { Areas }\end{array}$ \\
\hline A & 3.92 & 4.8 & 2.76 & 1 & $\begin{array}{l}\text { Kuttanadu, } \\
\text { Moncompu, } \\
\text { Thalavady }\end{array}$ \\
\hline B & 4.68 & 4.72 & 2.68 & 2 & $\begin{array}{l}\text { Bharanikavu, } \\
\text { Kidangara }\end{array}$ \\
\hline
\end{tabular}

Risk $=$ Threat $x$ Vulnerability $x$ Cost

Where, Threat $=$ Frequency of the event,

Vulnerability = Circumstances of a community ( 0 to 1$)$, Cost

$=$ Total cost of the impact of the threat.

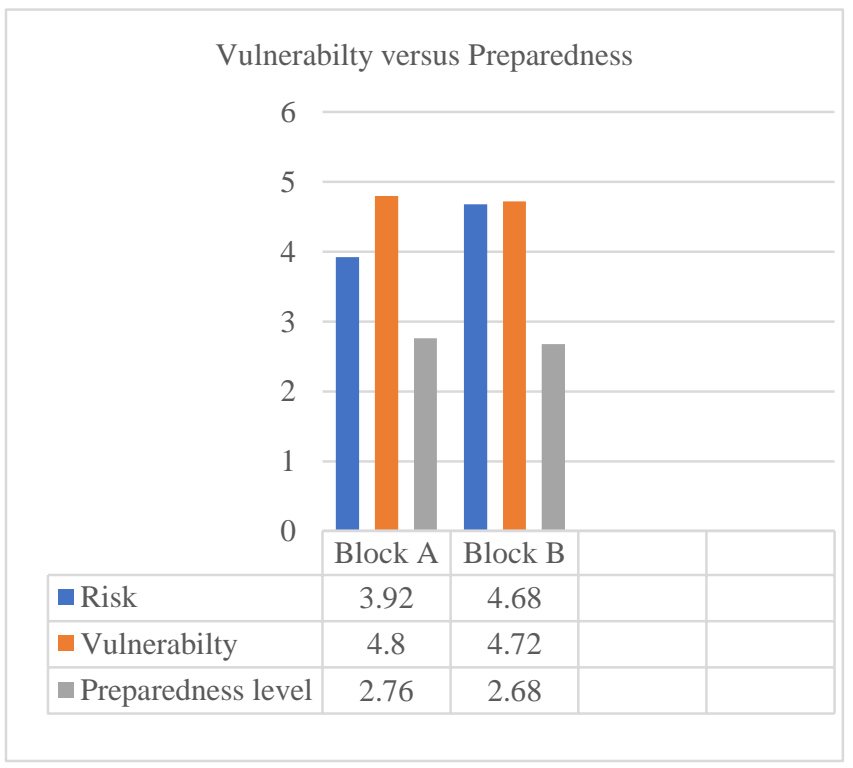

Chart -2: Vulnerability, Risk and Preparedness level of the area

The Chart 2 represents the vulnerability statistics of the community. The mean scale value is determined as 4.78 . It identifies the vulnerability areas, the level of preparedness and amount of risk from the study areas covered. It shows the vulnerability is high in area A with the vulnerability value of 4.8 and the risk value of 3.92 .

\subsection{Statistical Analysis using SPSS}

The Table 3 gives the output of internal consistency check (reliability check) performed using WPS Spreadsheet and SPSS software. It represents the Cronbach's Alpha value which is identified to be greater than 0.7 i.e. 0.761 and hence proved that the analysis carried out is successful for the determination of risk parameters.

Table -3: Reliability Analysis using SPSS

\begin{tabular}{|l|l|l|}
\hline $\begin{array}{l}\text { Cronbach's } \\
\text { Alpha }\end{array}$ & $\begin{array}{l}\text { Cronbach's Alpha Based } \\
\text { on Standardized items }\end{array}$ & of items \\
\hline 0.761 & 0.716 & 25 \\
\hline
\end{tabular}

The Table 4 shows the ranking for the countermeasures using SPSS for the risk in the area in the structural safety and non-structural safety.

Table -4: Counter measures ranking

\begin{tabular}{|c|c|c|c|}
\hline No & Components & Inference & Rank \\
\hline \multirow[t]{3}{*}{1} & $\begin{array}{l}\text { Flood Proofing } \\
\text { (Structural } \\
\text { safety) }\end{array}$ & $\begin{array}{l}\text { To avoid impacts of } \\
\text { flooding to the } \\
\text { structures }\end{array}$ & \multirow[t]{3}{*}{1} \\
\hline & $\begin{array}{l}\text { Dry Flood } \\
\text { Proofing }\end{array}$ & $\begin{array}{l}\text { Water tight below } \\
\text { flood level }\end{array}$ & \\
\hline & $\begin{array}{l}\text { Wet Flood } \\
\text { Proofing }\end{array}$ & $\begin{array}{l}\text { Using } \\
\text { resistant material } \\
\text { below flood depth, } \\
\text { breakaway walls to } \\
\text { allow water passage }\end{array}$ & \\
\hline 2 & $\begin{array}{l}\text { 72-Hour } \\
\text { Disaster Kit }\end{array}$ & $\begin{array}{l}\text { Collection of basic } \\
\text { items in an } \\
\text { emergency (Food, } \\
\text { water, first aid kit, } \\
\text { whistle to signal. }\end{array}$ & 2 \\
\hline \multirow[b]{2}{*}{3} & $\begin{array}{l}\text { Early Warning } \\
\text { System(EWS) }\end{array}$ & $\begin{array}{l}\text { a) Develop a system } \\
\text { to monitor and }\end{array}$ & \multirow[b]{2}{*}{3} \\
\hline & $\begin{array}{l}\text { Type- VHF } \\
\text { (Very high } \\
\text { frequency) } \\
\text { EWS } \\
\text { (A low-cost } \\
\text { solution) }\end{array}$ & $\begin{array}{l}\text { control the calamity. } \\
\text { b) Wireless } \\
\text { notification and play } \\
\text { warning messages } \\
\text { repeatedly. } \\
\text { d)Communicate via } \\
\text { VHF (Very high } \\
\text { frequency) radio - } \\
\text { A proposed system } \\
\text { It monitors sensor } \\
\text { networks installed } \\
\text { in flood defences } \\
\text { like dams, } \\
\text { embankments }\end{array}$ & \\
\hline 4 & $\begin{array}{l}\text { Flood } \\
\text { Directive (EU) }\end{array}$ & $\begin{array}{l}\text { a) Drawing up flood } \\
\text { risk assessment. } \\
\text { b) Identifying the } \\
\text { risk areas for } \\
\text { assessing, } \\
\text { improving and } \\
\text { managing the flood } \\
\text { risk. }\end{array}$ & 4 \\
\hline 5 & FRM Plans & $\begin{array}{l}\text { a) Flood Evacuation } \\
\text { Plan, warning } \\
\text { services, evacuation } \\
\text { plans } \\
\text { procedures. }\end{array}$ & 5 \\
\hline
\end{tabular}

The Table 5 shows the factor relationship with the preparedness level in the disaster. The highest affected factor has been identified as cost. 
Table -5: Factors that affects the level of preparedness in a disaster

\begin{tabular}{|l|l|}
\hline Correlational Factors & Rank \\
\hline Cost & 1 \\
\hline Time & 2 \\
\hline Knowledge & 3 \\
\hline Cooperation & 4 \\
\hline
\end{tabular}

For about 50 buildings covered, the type of building that has affected in the disaster includes residential building that has been shown in Table 6. Both analytical and statistical method of analysis has been done to rank the same with accuracy. The ranking shows that the residential building has affected the highest when compared to commercial and public buildings.

Table -6: Comparison for the type of building relates with

\begin{tabular}{|l|l|l|l|l|}
\hline Sl.No & Type & $\begin{array}{l}\text { Analytical } \\
\text { method } \\
\text { II value }\end{array}$ & $\begin{array}{l}\text { Statistical } \\
\text { method } \\
\text { Likert } \\
\text { Scale value }\end{array}$ & Rank \\
\hline 1 & $\begin{array}{l}\text { Residential } \\
\text { buildings } \\
\text { (33) }\end{array}$ & 76.89 & 4.5 & 1 \\
\hline 2 & $\begin{array}{l}\text { Commercial } \\
\text { buildings } \\
(10)\end{array}$ & 67.87 & 3.68 & 2 \\
\hline 3 & $\begin{array}{l}\text { Public } \\
\text { buildings (7) }\end{array}$ & 60.86 & 3.50 & 3 \\
\hline
\end{tabular}

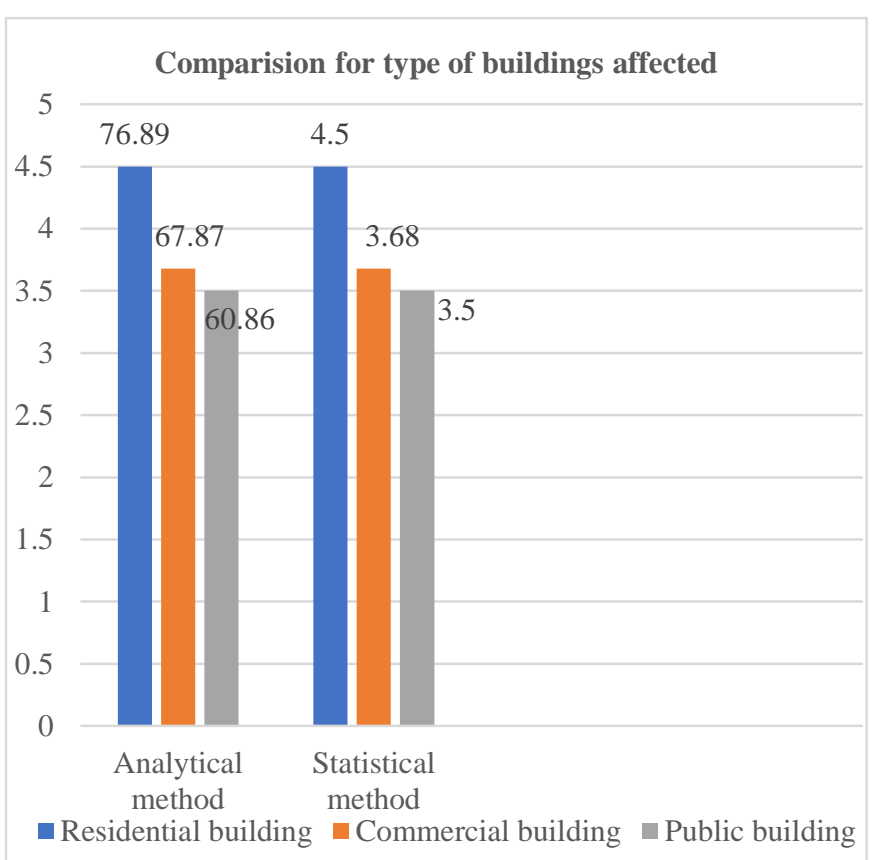

Chart -3: Comparison of type of building affected by disaster
The Chart 3 shows the comparison chart for the type of building affected in a disaster. The comparison has been determined by using Analytical Method and Statistical Method. The Table 5 shows the overall comparison between the parameters by using Analytical Method and Statistical Method and the ranking value is determined as same. Hence, the statistical method can be used to find out the ranking parameters for a disaster. The top 6 parameters are tabulated below. The highest rank 1 has a Likert scale value of 4.70 and Importance Index value as 94.8.

Table -7: Comparison between the parameters by using Analytical Method (II) and Statistical Method (Likert Scale)

\begin{tabular}{|c|c|c|c|c|c|}
\hline No & $\begin{array}{l}\text { Risk } \\
\text { Parameters }\end{array}$ & II & Rank & $\begin{array}{l}\text { Likert } \\
\text { Scale } \\
\text { Mean } \\
\end{array}$ & Rank \\
\hline 1 & $\begin{array}{l}\text { Development of } \\
\text { preparedness } \\
\text { tool is } \\
\text { necessary. }\end{array}$ & 94.8 & 1 & 4.70 & 1 \\
\hline 2 & $\begin{array}{l}\text { To what extend } \\
\text { do cost prevent } \\
\text { you } r \text { from } \\
\text { preparing for } \\
\text { flood. }\end{array}$ & 94.4 & 2 & 4.60 & 2 \\
\hline & $\begin{array}{l}\text { Emergency risk } \\
\text { plan }\end{array}$ & 94.4 & 2 & 4.60 & 2 \\
\hline 3 & $\begin{array}{lr}\text { Early } & \text { warning } \\
\text { system } & \text { is } \\
\text { needed } & \end{array}$ & 92.8 & 3 & 4.12 & 3 \\
\hline 4 & $\begin{array}{l}\text { Emergency } \\
\text { services. }\end{array}$ & 86.8 & 4 & 3.90 & 4 \\
\hline 5 & $\begin{array}{l}\text { Regular } \\
\text { preparedness } \\
\text { meeting and } \\
\text { training has } \\
\text { been conducted. }\end{array}$ & 83.6 & 5 & 3.85 & 5 \\
\hline 6 & $\begin{array}{l}\text { Emergency kit- } \\
\text { 72hr Disaster kit }\end{array}$ & 83.6 & 5 & 3.85 & 5 \\
\hline 7 & $\begin{array}{l}\text { Development of } \\
\text { FPP program is } \\
\text { needed. }\end{array}$ & 80.8 & 6 & 3.70 & 6 \\
\hline
\end{tabular}

As, from the result it is clearly determined that the development of tool is one of major risk parameters identified for the area. Lack of emergency risk plan, early warning system, preparedness meeting, an emergency disaster kit and FPP program lie under the lack of proper state disaster management plan. A plan has to be development for the problems and its effects. Therefore, a proposal for the disaster management plan is suggested below. 


\subsection{Development of the Disaster Management Plan}

Disaster management plan is the course of action develop to mitigate the damage of potential events that could endanger an organisations ability to function. This plan should include measures that provide for the safety of personnel and if possible property and facilities. The plan aims to make the state disaster resilient and significantly reduces the losses of life and damages to the structures. The Table 6 represents the disaster management plan proposed for the region.
From my study, the plan includes the risk factors identified and the countermeasures needed are the schemes provided, the phases include preparedness and mitigation. Also, the responsibility of the state i.e. the various organisations and their responsibility are denoted below. Both the structural and non-structural measures are proposed in the Disaster Risk Reduction (DRR) plan.

Table -8: Disaster Management Plan

\begin{tabular}{|c|c|c|c|}
\hline Scheme & Preparedness and Mitigation & State & Responsibility \\
\hline $\begin{array}{l}\text { Monitoring, } \\
\text { Forecasting, } \\
\text { Early warning } \\
\text { system }\end{array}$ & $\begin{array}{l}\text { Modernization of observation } \\
\text { network assessment, Monitoring } \\
\text { and scientific study }\end{array}$ & $\begin{array}{l}\text { SDMA, DDMA, } \\
\text { Panchayat }\end{array}$ & $\begin{array}{l}\text { Support and corporate with state } \\
\text { agencies, data collection. }\end{array}$ \\
\hline $\begin{array}{l}\text { Zoning and } \\
\text { classification of } \\
\text { flood prone areas }\end{array}$ & $\begin{array}{l}\text { Preparation of hazard maps of } \\
\text { flood prone areas of high } \\
\text { vulnerability }\end{array}$ & DDMA, Blocks & $\begin{array}{l}\text { Strengthening the ability of } \\
\text { communities to manage and cope } \\
\text { with disaster based on a multi } \\
\text { hazard approach. }\end{array}$ \\
\hline $\begin{array}{l}\text { Regulations, } \\
\text { Guidelines, } \\
\text { preparedness tool }\end{array}$ & $\begin{array}{l}\text { Regulatory framework for flood } \\
\text { plain zoning and flood } \\
\text { inundation management }\end{array}$ & $\begin{array}{l}\text { Revenue } \\
\text { department, } \\
\text { SDMA, CoR } \\
\text { (Commissioner of } \\
\text { Relief) }\end{array}$ & $\begin{array}{l}\text { Implementing land use regulation } \\
\text { for low lying areas, Prevention } \\
\text { and removal of encroachment in } \\
\text { the water ways and natural } \\
\text { drainage systems. }\end{array}$ \\
\hline $\begin{array}{l}\text { Training, FRM } \\
\text { Plans, Disaster kit }\end{array}$ & $\begin{array}{l}\text { Orientation programs, Search } \\
\text { and rescue in training programs, } \\
\text { Strengthen coverage of flood } \\
\text { damage mitigation }\end{array}$ & $\begin{array}{l}\text { SDMA, } \\
\text { Engineering } \\
\text { training institutes }\end{array}$ & $\begin{array}{l}\text { Protection of disaster affected } \\
\text { community }\end{array}$ \\
\hline
\end{tabular}

DRR Structural Measures

\begin{tabular}{|c|c|c|c|}
\hline Scheme & $\begin{array}{l}\text { Preparedness and } \\
\text { Mitigation }\end{array}$ & State & Responsibility \\
\hline $\begin{array}{l}\text { Regulations to promote } \\
\text { flood resistant buildings } \\
\text { and infrastructure and } \\
\text { adapting flood proofing. }\end{array}$ & $\begin{array}{l}\text { Proper alignment and } \\
\text { design, Preparing list } \\
\text { of structures due to } \\
\text { the disaster }\end{array}$ & $\begin{array}{l}\text { Local bodies, } \\
\text { Revenue } \\
\text { department, SDMA, } \\
\text { DDMA }\end{array}$ & $\begin{array}{l}\text { Undertake proper maintenance, } \\
\text { Revise and implement rules in } \\
\text { flood prone areas. }\end{array}$ \\
\hline $\begin{array}{l}\text { Flood control measures } \\
\text { such as construction of } \\
\text { embankment }\end{array}$ & Technical studies & $\begin{array}{l}\text { DDMA, Panchayat, } \\
\text { SDMA }\end{array}$ & $\begin{array}{l}\text { Identification of buildings which } \\
\text { are under risk, proper } \\
\text { maintenance of drainage system. }\end{array}$ \\
\hline $\begin{array}{l}\text { Flood water diversion } \\
\text { through existing or new } \\
\text { channels }\end{array}$ & $\begin{array}{l}\text { Studies to classify } \\
\text { vulnerable areas }\end{array}$ & $\begin{array}{l}\text { DDMA, Irrigation } \\
\text { department, SDMA }\end{array}$ & $\begin{array}{l}\text { Implementation as per norms or } \\
\text { rules. }\end{array}$ \\
\hline $\begin{array}{l}\text { Enhancing the type of } \\
\text { Dams and reservoirs }\end{array}$ & $\begin{array}{l}\text { Quick, clear, effective } \\
\text { dissemination among } \\
\text { state and central } \\
\text { agencies }\end{array}$ & $\begin{array}{l}\text { SDMA, Revenue } \\
\text { department, } \\
\text { Irrigation } \\
\text { department }\end{array}$ & $\begin{array}{l}\text { Carry out measures to increase } \\
\text { safety, reduce risks. }\end{array}$ \\
\hline $\begin{array}{l}\text { Water ways and drainage } \\
\text { system for roads and } \\
\text { highways }\end{array}$ & $\begin{array}{l}\text { Proper alignment and } \\
\text { design }\end{array}$ & $\begin{array}{l}\text { PWD, DDMA, } \\
\text { Panchayat, SDMA }\end{array}$ & $\begin{array}{l}\text { Coordination and cooperation } \\
\text { with state agencies and ensure } \\
\text { proper alignment and design in all } \\
\text { projects. }\end{array}$ \\
\hline
\end{tabular}




\section{CONCLUSION AND RECOMMENDATIONS}

The study gives the complete idea about the present frame work in the disaster management industry. The work discusses major causes, effects and control measures of preparedness level in Alleppey. The study examined whether the area is having a preparedness plan.

The risk parameters and in addition the comparison of correlational factors with preparedness level has been resolved. The most effective control measure is flood proofing, early warning system and FRM plans. And it is acknowledged by every respondent who involved in the projects. The prime parameters that leads to risk are also identified analytically and statistically. The analytical and statistical methods are compared simultaneously. It provides the similar outcomes which shows the time efficiency of SPSS instead of analytical method for future comparisons. As per the result, the development of a disaster management plan has been set up for future studies.

Embracing flood proofing technology to reduce the impacts of flooding and the implementation of early warning system (EWS) is a useful vehicle for assessing, improving and managing flood risk in the area. This study provides foundation for future research on state emergency management communication and can help disaster management team to evaluate their communication. Further study is needed to validate the accuracy for the similar risk parameters by using different methods and by comparing them.

\section{ACKNOWLEDGEMENT}

This material is based on the work supported by the internal supervisor Mr. Jawahar Saud S, the corresponding author. Special thanks for supplying the data from the District Disaster Management Agency, Kerala. We also thank the anonymous referees for their useful suggestions. All errors and omissions are the author's responsibility.

\section{REFERENCES}

[1]. Ardarshan A and Sohrabizadeh S (2014) Adapting flood preparedness tools to changing flood risk conditions: the situation in Iran, Vol 52, No: 2, pp 385-407.

[2]. Avakyan $\mathrm{AB}$ and Isomina $\mathrm{MN}$ (2011) Floods in the world late in the XX century, Water Resources, Vol 27: No:5 pp 469-475.

[3]. Baxter PJ (2005) The east coast big flood: A summary of the human disaster, Vol 363, No: 1831, pp 1293-1312.

[4]. Berg. G (2009) Flood disasters: Lessons learnt from past- worries for future. Proceedings of the institution of Civil Engineers, Vol 142, No:1., pp 3-8.

[5]. Dooley et.al (2000) Science and Technology for natural disaster reduction, Journal of Disaster management, ASCE, pp 1-12.

[6]. Guzzetti F, Stark CP, Salvati P (2005) Evaluation of flood and landslide risk to the population of Italy, Journal of Environmental Management, Vol36, No:1, pp15-36.
[7]. J. Simm, B. Gouldby, P. Sayers (2009) Representing fragility of flood defenses, Journal of Disaster Management, New York, pp 33-38.

[8]. Johny Joseph (2011) Disaster Management Plan for the state of Maharashtra, Journal of construction engineering and management, ASCE, pp 1-9.

[9]. Jonkman SN and Vrijling JK (2010) Loss of life due to floods. Journal of Disaster Management Vol 1, pp 43-56.

[10]. K Okazaki, Ahmad et.al (2008) Rethinking the nature of disaster, Journal of Natural Hazards Review, ASCE, Vol:87, No:2., pp 1115-1138.

[11]. Kerala State Disaster Management Authority (2013) Hazards review of Kerala, December., pp 1-78.

[12]. Kundzewicz Z, Guntry Korycka M (2007) Adaption of flood implication in Europe, Journal of water resource management, Vol: 51, No:3., pp 319-334.

[13]. Mc Clure et al (2001) Socio-economic impacts of major floods, Advances in Geoscience Vol 7, pp 223-229.

[14]. Mileti and Darlington (2000) Risk assessment and adapting reliable instrument for disaster, Natural Hazards Review, Vol:4, No:4., pp 206-212.

[15]. Nasim Uddin, Dennis (2012) Disaster management system for Southwestern Indiana, Natural Hazards review, ASCE, Vol:3, No:1., pp 19-30.

[16]. Li U, Brooke Fisher (2008) Online disaster preparation by using emergency websites, Annual flood report., pp 1-6.

[17]. Li Kungang (2003) Flood Management in China, Journal of Urban Planning and Development, ASCE, Vol:129, No:3., pp 140-158.

[18]. Ronald Fisher, Mary Hunt (2002) Disaster recovery plan and preparedness, Journal of Professional issues in Engineering education and Practice, ASCE Vol:121, No:4., pp 37-39.

[19]. St. Louis, Missori (2010) Improving flood preparedness and risk management, Journal of Scientific and Engineering research, ASCE, Vol 52, No: 1., pp 12-18.

[20]. Yu Xiao (2014) Adapting preparedness to reduce physical damages in disasters, Baltex Conference, Oceanologia, January., pp 386-407. 